\title{
Normative anthropometry and proportions of the Kenyan-African face and comparative anthropometry in relation to African Americans and North American Whites
}

Saurab S. Virdi ${ }^{1}$, David Wertheim ${ }^{2}$ and Farhad B. Naini ${ }^{3^{*}}$ (D)

\begin{abstract}
Background: There is no normative craniofacial anthropometric data for the Kenyan-African population. The purpose of this investigation was to determine normative anthropometric craniofacial measurements and proportional relationships for Kenyans of African descent and to compare the data with African Americans (AA), North American Whites (NAW), and neoclassical canons.

Methods: Twenty-five direct facial anthropometric measurements, and 4 angular measurements, were taken on 72 Kenyan-African participants (age range 18-30 years) recruited at the University of Nairobi in Kenya. The data were compared with AA and NAW populations, and neoclassical canons. Descriptive statistics of the variables were computed for the study population.

Results: Significant differences between both Kenyan males and females were detected in forehead height ( $\sim \mathrm{mm}$ greater for males, $\sim 4.5 \mathrm{~mm}$ for females), nasal height (reduced by $\sim 4 \mathrm{~mm}$ in males, $\sim 3 \mathrm{~mm}$ in females), nasal width (8-9 $\mathrm{mm}$ greater), upper lip height ( $>3 \mathrm{~mm}$ ), and eye width (greater by $\sim 3 \mathrm{~mm}$ ) compared to NAW subjects. All vertical measurements obtained were significantly different compared with NAW. Differences were observed in comparison with AA subjects, but less marked. Mouth width was similar in all groups. Angular measurements were variable. Neoclassical canons did not apply to the Kenyan population.

Conclusions: Anthropometric measurements of NAW showed clear differences when compared with the Kenyan population, and variations exist with comparative AA data. The anthropometric data in terms of linear measurements, angular measurements, and proportional values described may serve as a database for facial analysis in the KenyanAfrican population.
\end{abstract}

Keywords: Craniofacial anthropometry, Kenyan, Proportions, Normative values

\footnotetext{
* Correspondence: farhad.naini@yahoo.co.uk

${ }^{3}$ Kingston and St George's Hospitals and St George's Medical School,

London, UK

Full list of author information is available at the end of the article
} 


\section{Background}

Many patterns of growth, development, and treatment changes may be recorded with good levels of precision using anthropometry [1-5]. The first study to test the pertinence of neoclassical facial canons included samples of 6-, 12-, and 18-year-old North American Caucasians [4]. Over the years, the appropriateness of these canons has been tested in other ethnic groups including Indian [6, 7], African-American [8], Turkish [9], Vietnamese, Thai, and Chinese populations [10]. These anthropometric studies were performed by means of using direct manual methodology, such as spreading and sliding calipers, and have permitted the evaluation of numerous craniofacial measurements in various ethnic groups [11]. However, data on Kenyans of African descent is inadequate [12].

Anthropometric information provides useful data on the distribution of numerous measurements of human subjects, enabling the impartial appraisal of outcomes before and after treatment [13, 14]. Craniofacial anthropometry is an uncomplicated, economical, effective, and non-invasive process for quantitative analysis of craniofacial morphology and it involves taking direct clinical measurements such as linear distances, proportions, angles, and ratios [15]. Craniofacial anthropometry is appropriate for population studies because of the accessibility of comparative and conventional databases [15].

An extensively utilized collection of anthropometric measurements, comprising of 47 surface landmarks (Fig. 1), to develop facial canons in order to help in analyzing and describing the faces of North American Caucasians have been described [16]. These canons were subsequently tested on a variety of ethnic groups with participants from 13 European countries (Azerbaijan, Bulgaria, Croatia, Czech Republic, Germany, Greece, Hungary, Italy, Poland, Portugal, Russia, Slovakia, and Slovenia), 3 Middle Eastern countries (Egypt, Iran, and Turkey), 5 East Asian countries (India, Japan, the Chinese of Singapore, Vietnam, and Thailand), 3 African states (Angola, Tonga, and Zulu), and African Americans from the USA [16].

An investigation compared the Sudanese female (SF) face with those of African Americans (AA) and North American whites (NAW) and recognized differences, expressing that the neoclassical norms were unreliable guides to the SF face as they were considerably taller and narrower than the AA or NAW female face respectively [11]. Another investigation recognized that the typical AA female does not fit the neoclassical criterion of facial proportions, and varied considerably in the horizontal dimension measurements when compared to those of white subjects [17].

Photogrammetric analysis may be less accurate than anthropometric analysis [18]. Nevertheless, an investigation comprising the angular photogrammetric comparison of soft tissue profiles of 177 black Kenyans and 156 Chinese was undertaken, which established numerous contrasts in the typical angular measurements of facial profiles between black Kenyans, Chinese, and white standards [12]. Jeffries et al. [19] photogrammetrically examined 200 AA participants and compared the results with those of Farkas et al. [14]. They determined that AA and white participants had comparable vertical facial proportions, though the horizontal proportions varied considerably and were in accordance with previously published data [19]. Two investigations have noted that
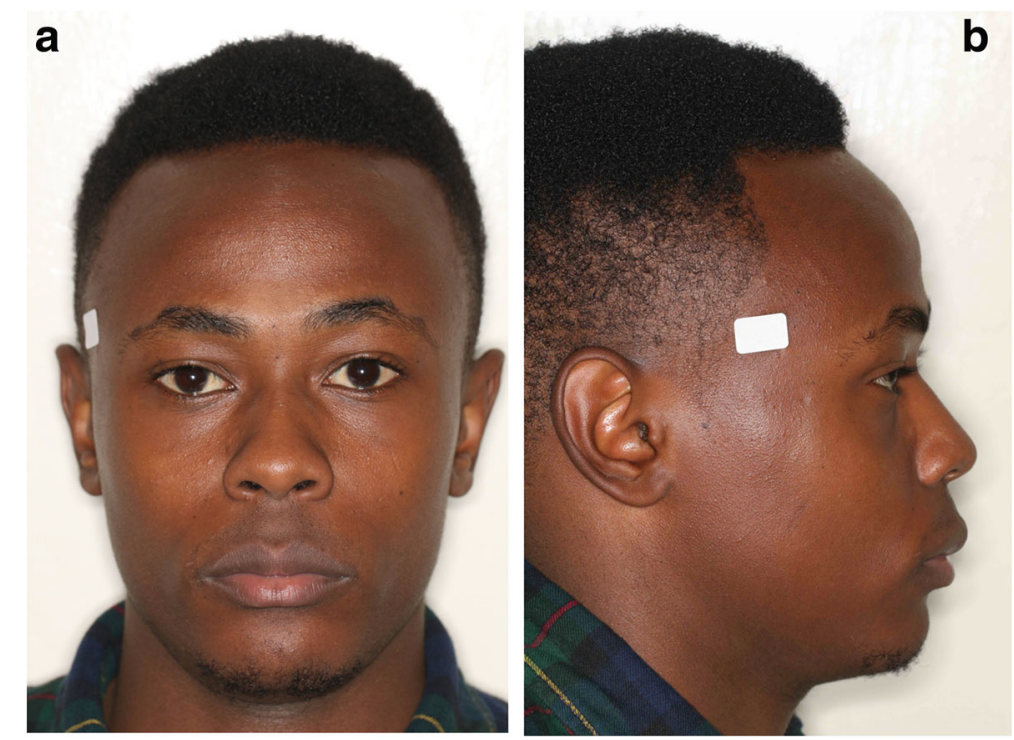

Fig. 1 a Frontal and $\mathbf{b}$ profile views of Kenyan African male 


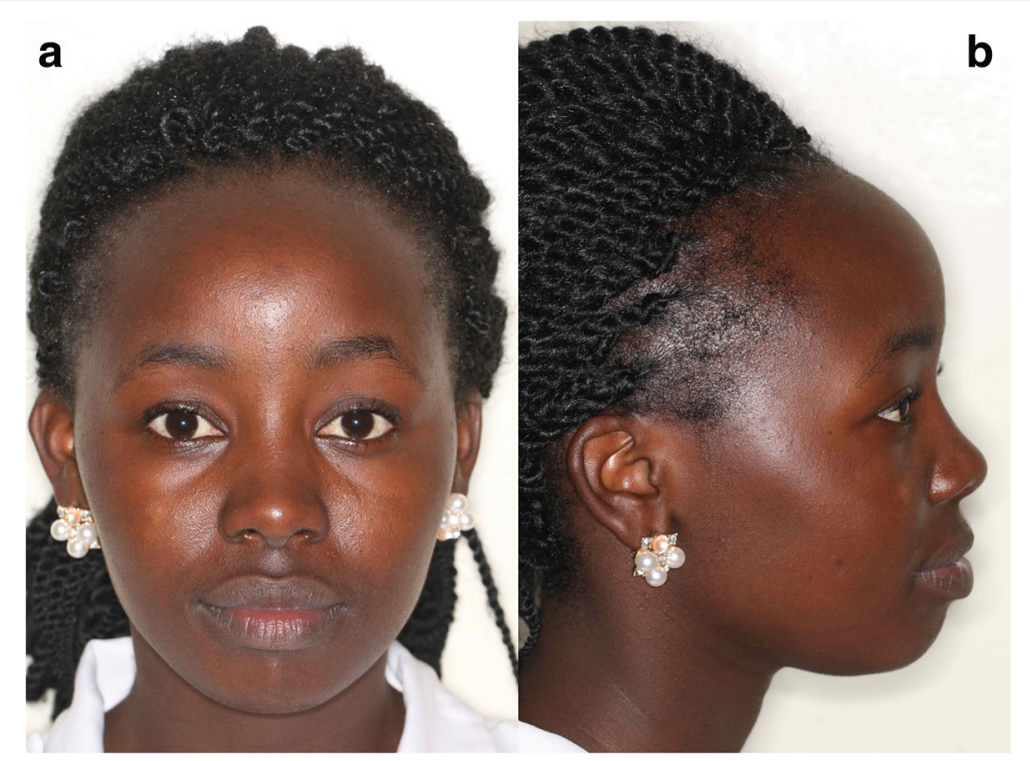

Fig. 2 a Frontal and $\mathbf{b}$ profile views of Kenyan African female

the South Indian population, in general, had a wider lower face while NAW showed wider midface and overall greater values of proportional indices than North American Caucasian population [6, 7]. A Turkish population study clearly shows anthropometric variation for fronto-occipital, circumference, intercanthal distance, outer canthal distance, near and distant interpupillary distance, canthal index, and circumference-interorbital index with age [9].

Normative craniofacial anthropometric values (linear, angular, and proportional) aid in diagnostic determination and treatment planning for patients, who come from diverse ethnic backgrounds and have need for esthetic and reconstructive dentofacial or craniofacial surgery. A database of normative values for each ethnic group is essential. Universally applied criteria of esthetic attractiveness and proportions may be misleading, due to ethnic variation, and dependence on neoclassical proportional canons, may be equally spurious [1]. To date, normative anthropometric data and comparative information that could be used for treatment planning in craniofacial and orthognathic surgery has been inaccessible for Kenyans of African descent. The proposed investigation aimed to gather the required normative data, and to assess the differences in facial proportions between Kenyan participants compared to those of African Americans (AA), North American Whites (NAW), and neoclassical canons.

\section{Methods}

\section{Subjects and materials}

Ethical approval was obtained from the University of Nairobi Ethics and Research Committee. The sample size was determined using simple sampling method based on previous anthropometric investigations $[11,17]$. This prospective cross-sectional investigation was undertaken at the University of Nairobi in Kenya.

The inclusion criteria were:

- Male and female participants (>18 years of age) studying at the University of Nairobi.

- Being of Kenyan descent (each participant was questioned regarding their family background and both sets of grandparents determined to be of Kenyan descent).

- No history of previous facial surgical procedure.

- Having average/normal facial appearance (as visually assessed by the lead investigator).

Each invited participant was provided with an information sheet and verbal information, and informed consent was obtained.

Ethical approval was granted by the Ethics and Research Committee, University of Nairobi (ref: KNH-ERC/A/289).

\section{Measurements and technique}

Subsequently, anthropometric measurements were taken with a digital vernier caliper, followed by frontal and profile facial photographs taken in a natural head position. A sliding digital vernier caliper was used to measure predetermined anthropometric facial parameters directly on each subject. These measurements were performed in agreement with well-established methods previously described [13]. The frontal and profile photograph of each participant was taken utilizing a standardized method with the participant in natural head position, the same camera to participant distance, the same background, and comparable illumination by means of a digital camera, a Canon 70D (with macro lens 100 and Macro Ring Flash II). 
All measurements were collected by one author (SSV) with the subjects' head in natural head position, and recorded in millimeters.

Figures 1 and 2 demonstrate examples of a male and a female Kenyan subject participating in this investigation. Figure 3 illustrates the principal facial soft tissue landmarks, permitting the linear and angular measurements used in this investigation.

The following were the principal measurements undertaken (Fig. 3):

- Head: tr-n and tr-g (forehead height)

- Orbits: en-en (intercanthal distance), ex-ex (biocular width), en-ex (eye fissure length)

- Face: $\mathrm{ft}-\mathrm{ft}$ (bitemporal width), zy-zy (bizygomatic face width), go-go (bigonial width), tr-me (physiognomical face height), n-me (morphological face height), g-sn (midface height), sn-me (lower face height

- Nose: al-al (Morphological nose width), ac-ac (nasal alar base width), n-sn (nose height)

- Labio-oral region: ch-ch (mouth width), sn-ls (philtrum height), sn-sto (upper lip height), ls-sto (upper vermilion height), sto-li (lower vermilion height), sto-lmf (lower lip height), lmf-me (chin height)

- Angular measurements: nasofrontal, nasolabial, labiomental, and submental-cervical.

\section{Measurement error and reliability}

An intra-examiner reliability test was performed with five subjects and their measurements recorded at two different times, 2 weeks apart.

\section{Statistical analysis}

Data analysis was undertaken using Microsoft Excel 2010 (Microsoft Corporation, USA) and Minitab version 16 (Minitab Inc., USA) software for Windows. Descriptive statistics of the variables were computed for the study population. Two-sample $t$ tests were used to compare the distribution means of ten measurements, horizontal and vertical with published NAW and AA data $[8,20]$. For some measurements, there was insufficient data available to compare using the two-sample $t$ tests; hence one-sample $t$ tests were used to compare these data from the Kenyan participants with the North American white and African American mean values, to provide an indication of differences. Intraexaminer reliability was analyzed using the formula proposed by Dahlberg that determined method error $(\mathrm{ME})=\sqrt{ } \Sigma\left(x_{1}-x_{2}\right)^{2} / 2 n$ where $x_{1}$ is the first measurement, $x_{2}$ the second measurement, and $n$ is the number of repeated records. Measurements of five participants' were repeated at an interval of 2 weeks to enable assessment of repeatability (Fig. 4).

\section{Results}

\section{Examiner reliability}

The results of intraexaminer reliability were calculated using the Bland-Altman test, Dahlberg method, and absolute difference divided by the mean. All the methods showed a low method error that was generally less than $0.5 \mathrm{~mm}$ for linear measurements (vertical and horizontal) and $<2.4^{\circ}$ for angular measurements, which is considered acceptable (Fig. 1, Table 1).
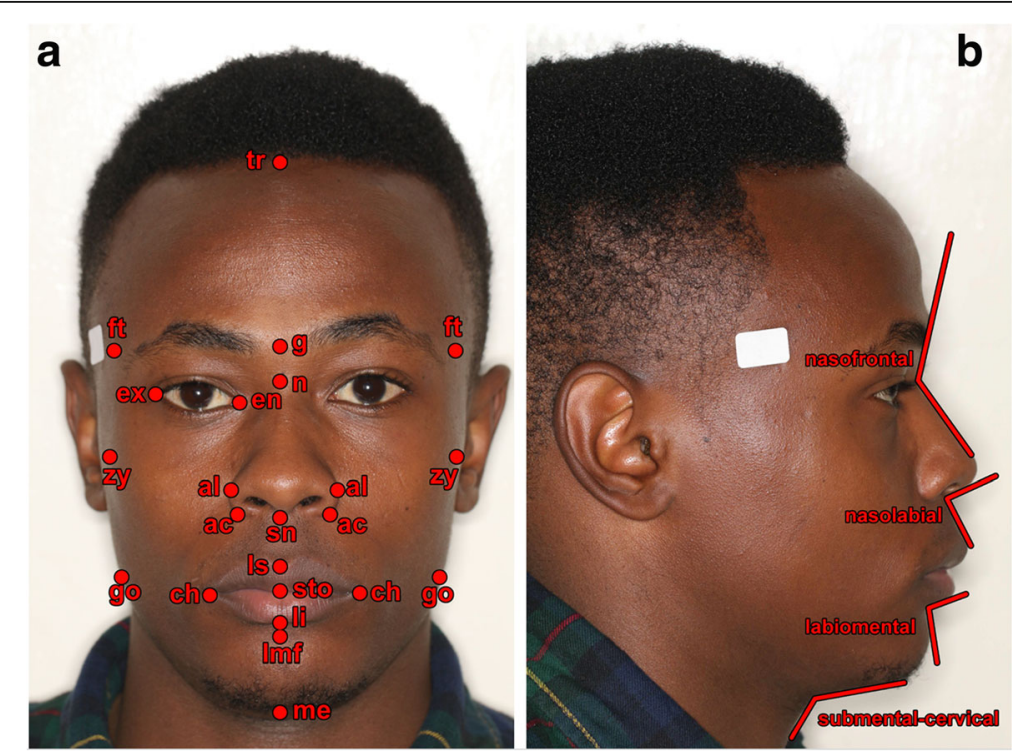

Fig. 3 a Frontal view demonstrating principal soft tissue landmarks used for linear measurements: tr trichion, $g$ glabella, $n$ nasion, sn subnasale, Is labrale superius, sto stomion, li labrale inferius, Imf labiomental fold, me menton, $f t$, frontotemporale, zy zygion, go gonion, ex exocanthion, en endocanthion, al alare, ac alar curvature point, ch cheilion. b Profile view demonstrating angular measurements 

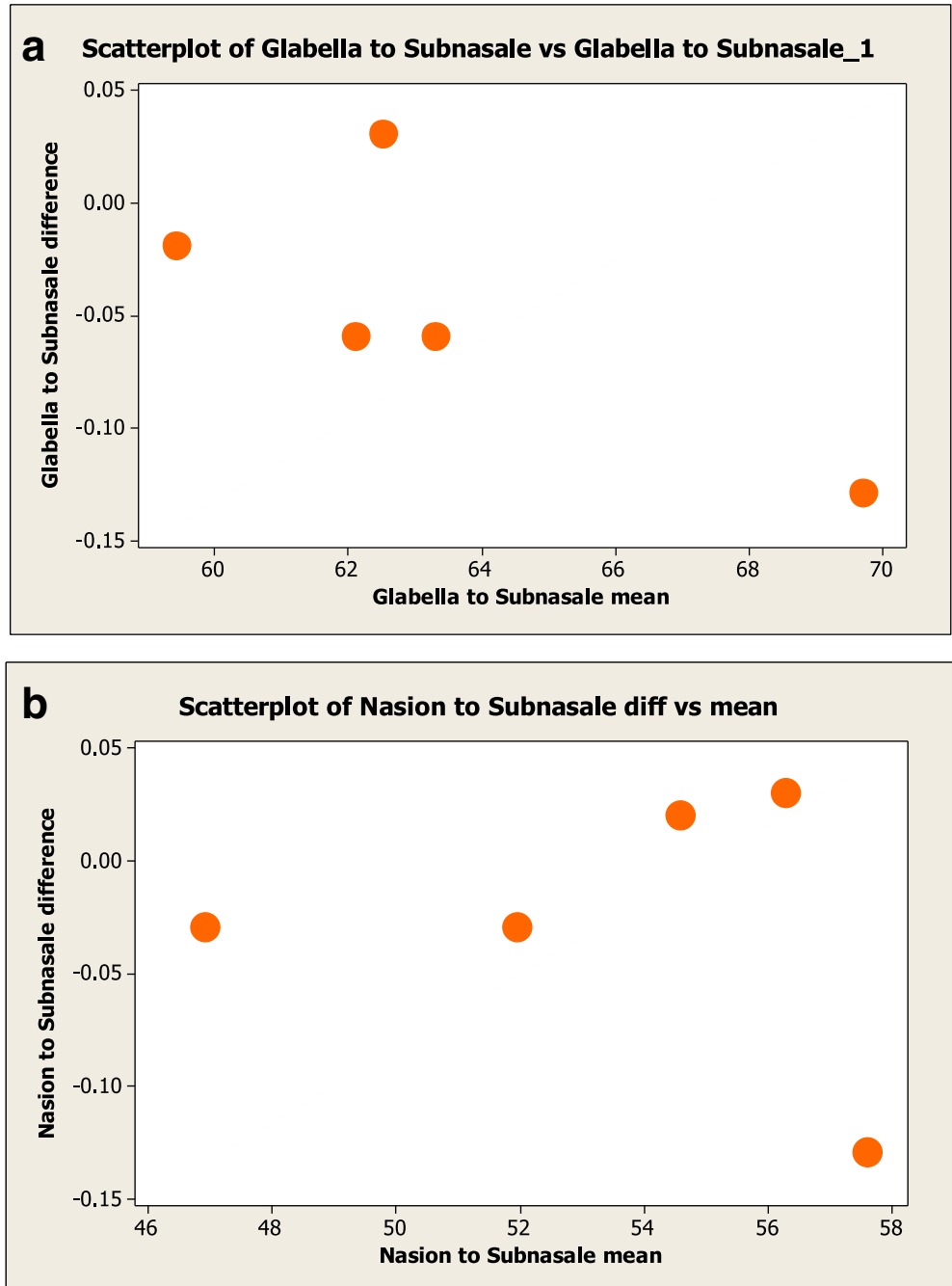

Fig. 4 Scatterplot of vertical facial measurements, permitting examination of trends in the relationships, and changes in spread of one variable as a function of the other. a Glabella to subnasale. $\mathbf{b}$ Nasion to subnasale

\section{Principal measurements}

Descriptive statistics for vertical and horizontal measurements for the Kenyan male and female are given in Tables 2 and 3. Tables 4 and 5 show the angular measurements of the Kenyan male and female face compared with the North American White (NAW) and African American (AA) populations.

In view of multiple comparisons, the level taken for significance in these studies was $p<0.001$. For five vertical and five horizontal measurements, and three angular measurements, all the comparative data were available from Farkas et al. [8] thus allowing analysis using two-sample $t$ tests. Clinically significant differences were based on the ability to detect a difference greater than $3 \mathrm{~mm}$ between the two equal halves of the face. Farkas et al. [8] considered differences of up to $2 \mathrm{~mm}$ to be within normal range, hence the cut-off minimum was set at $3 \mathrm{~mm}$.
To date, only one study has suggested a threshold of a clinically relevant difference expressed in degrees [21]. In this investigation, the clinically significant difference was set at $10^{\circ}$, in order to demonstrate differences that were clinically significant and visually identifiable, perhaps even to the untrained eye.

\section{Specific Kenyan-African craniofacial data}

The following results were obtained:

Head: Forehead height (tr-n) of all the Kenyan males and females were increased compared to the North American whites $(p<0.001)$ (clinically significant $>3 \mathrm{~mm}$ ) and were similar to the African American population (male $p=0.85$ and female $p=0.693$ ) (Tables 2 and 3).

Labio-oral region: The mouth width (ch-ch) was larger by $1.4 \mathrm{~mm}$ compared with NAW, and $1.3 \mathrm{~mm}$ to AA, though not clinically significant, $(p=0.027)$ and $(p=0.106)$, respectively. Similarly, the Kenyan female had a greater 
Table 1 Dahlberg coefficient of horizontal and vertical measurements

\begin{tabular}{|c|c|c|}
\hline Vertical measurements & Dahlberg coefficient & \\
\hline Trichion to Glabella & 0.041 & \\
\hline Trichion to Nasion & 0.083 & \\
\hline Glabella to Subnasale & 0.050 & \\
\hline Nasion to Subnasale & 0.045 & \\
\hline Subnasale to Soft tissue menton & 0.018 & \\
\hline Upper lip height & 0.046 & \\
\hline Lower lip height & 0.086 & \\
\hline Philtrum height & 0.050 & \\
\hline Lateral commissure height & 0.043 & \\
\hline Vermillion height Upper & 0.039 & \\
\hline Vermillion height Lower & 0.033 & \\
\hline Chin height & 0.058 & \\
\hline $\begin{array}{l}\text { Lower lip to labiomental fold } \\
\text { (LMF) }\end{array}$ & 0.339 & \\
\hline LMF (depth) & 0.043 & \\
\hline Lower lip to Soft tissue menton & 0.076 & \\
\hline Horizontal measurements & Dahlberg coefficient & Mean (abs diff/mean) (\%) \\
\hline Ex-Ex & 0.036 & 0.053 \\
\hline Medial canthus to lateral canthus (ex-en) & 0.024 & 0.101 \\
\hline En-En & 0.022 & 0.050 \\
\hline Right ala to left ala (al-al) & 0.029 & 0.063 \\
\hline $\begin{array}{l}\text { Right ala curvature to left ala } \\
\text { curvature (ac-ac) }\end{array}$ & 0.235 & 0.993 \\
\hline Mouth width (ch-ch) & 0.054 & 0.105 \\
\hline Bitemporal width (ft-ft) & 0.027 & 0.042 \\
\hline Bizygomatic width (zy-zy) & 0.575 & 0.395 \\
\hline Bigonial width (go-go) & 0.024 & 0.027 \\
\hline
\end{tabular}

Table 2 Comparison with Farkas et al. [8] data using two-sample $t$ tests (Kenyan males)

\begin{tabular}{|c|c|c|c|c|c|}
\hline \multicolumn{6}{|l|}{ Kenyan male face } \\
\hline & KM Mean $(n=36)$ & NAW (SD) $(n-109)$ & $P$ value & $\mathrm{AA}(\mathrm{SD})(n=50)$ & $P$ value \\
\hline \multicolumn{6}{|l|}{ Vertical measurements } \\
\hline Forehead height II tr-n & $72.2(2.3)$ & $67.1(7.5)$ & $<0.001^{*}$ & $72.0(7.7)$ & 0.850 \\
\hline Nasal height n-sn & $51.0(1.9)$ & $54.8(3.3)$ & $<0.001^{*}$ & $51.9(3.0)$ & 0.077 \\
\hline Lower face height sn-me & $76.4(3.6)$ & $72.6(4.5)$ & $<0.001^{*}$ & $78.9(6.7)$ & 0.025 \\
\hline Upper lip height sn-sto & $25.5(1.3)$ & $22.3(2.1)$ & $<0.001^{*}$ & $26.1(2.5)$ & 0.107 \\
\hline Lower lip height sto-sl & $22.5(1.9)$ & $19.7(2.1)$ & $<0.001^{*}$ & $22.5(1.9)$ & 0.402 \\
\hline \multicolumn{6}{|l|}{ Horizontal measurements } \\
\hline Intercanthal distance en-en & $32.2(1.9)$ & $33.3(2.7)$ & 0.011 & $35.8(2.8)$ & $<0.001^{*}$ \\
\hline Eye width ex-en & $34.0(3.4)$ & $31.3(1.3)$ & $<0.001^{*}$ & $32.9(1.7)$ & 0.094 \\
\hline Biocular width ex-ex & $98.2(3.5)$ & $91.2(3.0)$ & $<0.001^{*}$ & $96.8(4.5)$ & 0.110 \\
\hline Nasal width al-al & $43.2(3.8)$ & $34.9(2.1)$ & $<0.001^{*}$ & $44.1(3.4)$ & 0.234 \\
\hline Mouth width ch-ch & $55.9(3.3)$ & $54.5(3.0)$ & 0.027 & $54.6(4.1)$ & 0.106 \\
\hline
\end{tabular}


Table 3 Comparison with Farkas et al. [8] data using two-sample $t$ tests (Kenyan females)

\begin{tabular}{|c|c|c|c|c|c|}
\hline \multicolumn{6}{|l|}{ Kenyan female face } \\
\hline & KF mean $(n=36)$ & NAW (SD) $(n-200)$ & $P$ value & $\mathrm{AA}(\mathrm{SD})(n=50)$ & $P$ value \\
\hline \multicolumn{6}{|l|}{ Vertical measurements } \\
\hline Forehead height II tr-n & $67.5(2.9)$ & $63.0(6.0)$ & $<0.001^{*}$ & $67.1(5.9)$ & 0.693 \\
\hline Nasal height n-sn & $47.6(3.1)$ & $50.6(3.1)$ & $<0.001^{*}$ & $48.8(3.7)$ & 0.114 \\
\hline Lower face height sn-me & $69.5(4.8)$ & $64.3(4.0)$ & $<0.001^{*}$ & $71.5(5.2)$ & 0.061 \\
\hline Upper lip height sn-sto & $24.0(2.5)$ & $20.1(2.0)$ & $<0.001^{*}$ & $24.5(3.0)$ & 0.435 \\
\hline Lower lip height sto-sl & $20.7(1.1)$ & $17.8(4.7)$ & $<0.001^{*}$ & $20.2(2.4)$ & 0.163 \\
\hline \multicolumn{6}{|l|}{ Horizontal measurements } \\
\hline Intercanthal distance en-en & $32.1(1.4)$ & $31.8(2.3)$ & 0.225 & $34.4(0.5)$ & $<0.001^{*}$ \\
\hline Eye width ex-en & $33.7(1.5)$ & $30.7(1.2)$ & $<0.001^{*}$ & $32.2(2.0)$ & 0.087 \\
\hline Biocular width ex-ex & $94.4(4.9)$ & $87.8(3.2)$ & $<0.001^{*}$ & $92.9(5.3)$ & 0.185 \\
\hline Nasal width al-al & $40.7(3.7)$ & $31.4(2.0)$ & $<0.001^{*}$ & $40.1(3.2)$ & 0.411 \\
\hline Mouth width ch-ch & $52.0(4.0)$ & $50.2(3.5)$ & 0.012 & $53.6(4.0)$ & 0.073 \\
\hline
\end{tabular}

${ }^{*}$ Clinically significant difference set at $\pm 3 \mathrm{~mm}$

mouth width $(1.8 \mathrm{~mm}, p=0.012)$ compared with NAW, though was smaller compared with AA $(-1.6 \mathrm{~mm})$; this was not statistically significant $(p=0.073)$ (Tables 2 and 3$)$.

Facial region: Of the ten measurements tested, the five vertical ones (tr-n, n-gn, sn-me, sn-sto, sto-sl) showed a significant difference $(p<0.001)$ compared with those of NAW and were similar to AA in both sexes, with no statistical difference detected (Tables 2 and 3).

Orbits: Eye fissure (en-ex) was increased in the Kenyan male compared with the NAW by $2.65 \mathrm{~mm}(p<0.001)$, and the AA by $1.1 \mathrm{~mm}(p=0.094)$. A similar result was observed in the Kenyan females compared with NAW and AA with a mean difference of $3.0 \mathrm{~mm}(p<0.001)$ and $1.5 \mathrm{~mm}(p<0.001)$, respectively (Tables 2 and 3 ). The biocular width (ex-ex) was significantly greater compared with the NAW with a mean difference of $7 \mathrm{~mm}(p<0.001)$ in the males and $6.6 \mathrm{~mm}(p<0.001)$ in the females. The differences were not significant when compared with the AA group ( $p=0.110$ in males and $p$ $=0.185$ in females) though the Kenyan females had a greater mean difference of $1.4 \mathrm{~mm}$ compared with the AA population (Tables 2 and 3).

Nose: Nose height ( $\mathrm{n}$-sn) was reduced by a mean difference of $3.8 \mathrm{~mm}(p<0.001)$ in the Kenyan male and $3.0 \mathrm{~mm}(p<0.001)$ in Kenyan females compared with the NAW. Both males and females had slightly reduced mean height differences compared to the AA, though this was not significant $(p=0.077$ in males, $p=0.114$ in females). However, nasal width (al-al) was greater and extremely significant with a mean difference of $8.3 \mathrm{~mm}$ $(p<0.001)$ in males and $9.3 \mathrm{~mm}(p<0.001)$ in females. These measurements were almost identical when compared with the AA populations, with a mean difference of $-1.0 \mathrm{~mm}(p=0.234)$ in the males and $0.6 \mathrm{~mm}(p=$ 0.411 ) in the females (Tables 2 and 3). The nasolabial and labiomental angular measurements of the Kenyan African male had a clinically significant difference of $10^{\circ}$ when compared with the North American white and the African American subjects (Table 4). In the Kenyan females, only the nasolabial angle had a clinically significant difference when compared with the NAW and AA populations. No significant difference was observed when compared to NAW, though a clinical significance was observed in the labiomental angle when compared to the AA female (Table 5).

\section{Comparative craniofacial data \\ Comparative data with NAW and AA}

For all the above measurements, there were clear clinically significant differences between Kenyan cohort male subjects compared with NAW $(p<0.001)$, except for en-en $(p=0.011)$ and mouth width (ch-ch) $(p=0.027)$. In contrast, when comparing with the AA male cohort, there were no clinically significant differences, except

Table 4 Angular measurements: two-sample $t$ test for Kenyan males

\begin{tabular}{|c|c|c|c|c|c|c|c|c|}
\hline Kenyan male $(n=34)$ & Mean & SD & NAW mean $(n=50)$ & SD & $P$ value & AA mean $(n=50)$ & SD & $P$ value \\
\hline Nasofrontal & 127.3 & 9.0 & 130.3 & 7.4 & 0.107 & 126.5 & 12.0 & 0.741 \\
\hline Nasolabial & 85.5 & 10.1 & 99.8 & 11.8 & 0.001 & 71.4 & 14.5 & 0.001 \\
\hline Labiomental & 128.2 & 10.8 & 113.5 & 20.7 & 0.001 & 101.5 & 17.7 & 0.001 \\
\hline Submental-cervical & 109.1 & 14.5 & & & & & & \\
\hline
\end{tabular}


Table 5 Angular measurements: two-sample $t$ test for Kenyan females

\begin{tabular}{lllllllll}
\hline Kenyan female $(n=36)$ & Mean & SD & NAW mean $(n=50)$ & SD & $P$ value & AA mean $(n=50)$ & SD & $P$ value \\
\hline Nasofrontal & 127.9 & 3.0 & 134.3 & 7.0 & 0.001 & 127.6 & 8.1 & 0.786 \\
Nasolabial & 85.2 & 13.8 & 104.2 & 9.8 & 0.001 & 73.9 & 14.5 & 0.001 \\
Labiomental & 116.9 & 21.1 & 121.4 & 14.4 & 0.269 & 101.6 & 18.0 & 0.001 \\
Submental-cervical & 109.1 & 14.5 & & & & & \\
\hline
\end{tabular}

the intercanthal distance (en-en) $(p<0.001)$. Similar results were obtained with the Kenyan female data, with all measurements demonstrating clinically significantly differences from NAW, except en-en $(p=0.225)$, mouth width (ch-ch) ( $p=0.012$, borderline), and compared with AA no clinically significant differences except a marginal intercanthal distance difference (en-en) $(p<0.001)$.

In terms of differences compared to the mean (one-sample $t$ test), when comparing the Kenyan male face to NAW, of the 22 measurements taken, 10 of the vertical measurements and 5 of the horizontal measurements showed statistically significant differences. Clinical significant differences were observed in nine vertical measurements and four horizontal measurements (Table 6).

The greatest difference in measurements was noted for the reduced nasal height, the increased interalar width, and nasal curvature. The only measurement that demonstrated similarity was the lower lip to the labiomental fold, having a mean difference of $0.3 \mathrm{~mm}$.

When compared with the African American population, only two vertical and two horizontal measurements showed a statistically significant difference. The following values are expressed as mean difference with standard deviation. The Kenyan male face had a shorter midface and lower face height, with a mean difference of $-4.0 \mathrm{~mm}$ (6.51) and $-2.6 \mathrm{~mm}$ (3.55), respectively, and philtrum height of $-0.9 \mathrm{~mm}$ (1.25). The two measurements that displayed significant difference were the intercanthal distance and the bizygomatic width. Clinically, no significant difference was found in the vertical measurements, but two horizontal measurements were clinically significant, bizygomatic width $(-4.9 \mathrm{~mm})$ and intercanthal distance $(-3.6 \mathrm{~mm})$, both being reduced in the Kenyan male face.

Across the three populations, the only measurement that showed statistically significant difference was the lower face height, which was increased compared with NAW and decreased compared with AA. The only measurement that had a clinical significant difference was observed in the Kenyan male with the bizygomatic width, which was reduced when compared with both NAW and AA males. This was not observed in the female subjects.

The Kenyan female face, when compared to the NAW, demonstrated a significant difference of 14 measurements of the 22 carried out. The forehead height
$2.7 \mathrm{~mm}(3.3)(p<0.001)$, midface height $\sim 2.2 \mathrm{~mm}(5.7)$ $(p<0.001)$, and lower face height $4.8 \mathrm{~mm}(p<0.001)$ were increased in the Kenyan female compared to the NAW. However, compared to the AA, there was no statistical difference in the forehead $\sim-0.3 \mathrm{~mm}(3.3)(p=$ $0.545)$, midface $\sim 0.7 \mathrm{~mm}(5.7)(p=0.481)$, and lower face heights $\sim-2.0 \mathrm{~mm}(4.8)(p=0.013)$. Only two measurements, intercanthal distance $\sim-2.3 \mathrm{~mm}(1.4)(p<$ $0.001)$ and eye width $\sim 1.5 \mathrm{~mm}(1.5)(p<0.001)$, showed a statistically significant difference.

The nasal height was reduced compared with both the NAW and AA though not statistically different when compared to the AA. Across the three populations, the only measurement of the Kenyan female face that showed a statistically significant difference was the eye width, having a mean difference of $\sim 3.0 \mathrm{~mm}$ (1.5) NAW and $~ 1.5 \mathrm{~mm}$ (1.5) AA.

Overall, when both the Kenyan male face and female face were compared with the NAW, the greatest differences were found in the measurements of the reduced nasal height $\sim-3.8 \mathrm{~mm}(1.9)(p<0.001)$ and increased nasal width $\sim 8.3 \mathrm{~mm}(3.8)(p<0.001)$, which were clinically significant. When compared with the AA, the only statistically significant difference in both males and females was the reduced intercanthal distance $\sim-3.6 \mathrm{~mm}$ (1.9) $(p<0.001)$ in the Kenyan population. However, this measurement was only clinically significant in the male participants.

\section{Comparative data with neoclassical proportional canons}

Seven neoclassical canons (Table 7) and five proportional indices (Table 8) were also investigated in the Kenyan sample. Most of the sample ratios did not comply with the neoclassical canons. When comparing the Kenyan male and Kenyan female to the neoclassical canons, the only canon which was valid for the majority of participants was the orbital canon (Canon VI). This was observed in 12 males and 10 female participants. For the vertical measurement, the forehead height exceeded the nasal height in the entire sample. Only $6 \%$ of males and $11 \%$ of females had forehead height equal to the lower facial height, with the majority demonstrating reduced lower face height compared to the forehead height. For the naso-oral canon, none of the participant's measurements demonstrated similarity, with $6 \%$ of males and $11 \%$ of females of the participants having 
Table 6 Comparison of the average facial measurements of the Kenyan male (KM) face and Kenyan female (KF) face with North American whites. NAW data from Farkas et al. $[8,14,20]$ and the African-American data from Farkas et al. [8] using one-sample $t$ test

\begin{tabular}{|c|c|c|c|c|c|}
\hline & $\begin{array}{l}\text { KM mean } \\
(\mathrm{SD})(n=36)\end{array}$ & $\begin{array}{l}\text { NAW mean (SD) } \\
\text { difference }(n=109)\end{array}$ & $P$ value & $\begin{array}{l}\text { AA mean (SD) } \\
\text { difference }(n=50)\end{array}$ & $P$ value \\
\hline \multicolumn{6}{|l|}{ Kenyan male face } \\
\hline \multicolumn{6}{|l|}{ Vertical measurements } \\
\hline Forehead height I (tr-g) & $61.4(3.2)$ & $4.4(3.2)$ & $<0.001$ & $-0.4(3.2)$ & 0.496 \\
\hline Forehead height II (tr-n) & $72.2(2.3)$ & $5.1(2.3)$ & $<0.001$ & $0.2(2.3)$ & 0.576 \\
\hline Midface height (g-sn) & $64.8(6.5)$ & $-2.4(6.5)$ & 0.033 & $-4.0(6.5)$ & 0.001 \\
\hline Nasal height (n-sn) & $51.0(1.9)$ & $-3.8(1.9)$ & $<0.001$ & $-0.9(1.9)$ & 0.005 \\
\hline Lower face height (sn-me) & $76.4(3.6)$ & $3.8(3.6)$ & $<0.001$ & $-2.6(3.6)$ & $<0.001$ \\
\hline Upper lip height (sn-sto) & $25.5(1.3)$ & $3.1(1.3)$ & $<0.001$ & $-0.7(1.3)$ & 0.004 \\
\hline Lower lip height (sto-sl) & $22.5(1.9)$ & $2.8(1.9)$ & $<0.001$ & $0.4(1.9)$ & 0.230 \\
\hline Philtrum height (sn-ls) & $15.5(1.3)$ & $-0.4(1.3)$ & 0.072 & $-0.9(1.3)$ & $<0.001$ \\
\hline Lateral commissure height & $23.5(2.6)$ & & & & \\
\hline Upper vermillion height (Is-sto) & $13.7(1.3)$ & $5.9(1.3)$ & $<0.001$ & $0.1(1.3)$ & 0.726 \\
\hline Lower vermillion height (sto-li) & $13.8(0.9)$ & $4.5(0.9)$ & $<0.001$ & $0.0(0.9)$ & 0.903 \\
\hline Chin height (fml-me) & $36.5(3.1)$ & $3.4(3.1)$ & $<0.001$ & $0.5(3.1)$ & 0.307 \\
\hline Lower lip to labiomental fold & $12.1(1.9)$ & $0.2(1.9)$ & 0.473 & $0.3(1.9)$ & 0.021 \\
\hline Labiomental fold & $8.2(1.9)$ & & & & \\
\hline Lower lip to menton & $56.2(3.5)$ & $8.2(3.4)$ & $<0.001$ & $-1.3(3.5)$ & 0.037 \\
\hline Nasion to menton & $101.8(3.6)$ & & & & \\
\hline \multicolumn{6}{|l|}{ Horizontal measurements } \\
\hline Intercanthal distance (en-en) & $32.2(1.9)$ & $-1.1(1.9)$ & 0.002 & $-3.6(1.9)$ & $<0.001$ \\
\hline Eye width (ex-en) & $34.0(3.4)$ & $2.7(3.4)$ & $<0.001$ & $1.1(3.4)$ & 0.071 \\
\hline Biocular width (ex-ex) & $98.2(3.5)$ & $7.0(3.5)$ & $<0.001$ & $1.4(3.5)$ & 0.021 \\
\hline Nasal width (al-al) & $43.2(3.8)$ & $8.3(3.8)$ & $<0.001$ & $-1.0(3.8)$ & 0.139 \\
\hline Ala curvature (ac-ac) & $41.3(3.1)$ & $8.5(3.1)$ & $<0.001$ & $1.3(3.1)$ & 0.019 \\
\hline Mouth width (ch-ch) & $55.9(3.3)$ & $1.4(3.3)$ & 0.014 & $1.3(3.3)$ & 0.022 \\
\hline Bitemporal width (ft-ft) & $115.3(3.4)$ & $-0.6(3.4)$ & 0.273 & $-1.0(3.4)$ & 0.077 \\
\hline Bizygomatic width (zy-zy) & $133.8(4,6))$ & $-5.3(4.6)$ & $<0.001$ & $-4.9(4.6)$ & $<0.001$ \\
\hline Bigonial width (go-go) & $106.6(5.9)$ & $1.0(5.9)$ & 0.312 & $2.4(5.9)$ & 0.019 \\
\hline \multicolumn{6}{|l|}{ Kenyan female face } \\
\hline \multicolumn{6}{|l|}{ Vertical measurements } \\
\hline Forehead height I (tr-g) & $55.4(3.3)$ & $2.7(3.3)$ & $<0.001$ & $-0.3(3.3)$ & 0.545 \\
\hline Forehead height II (tr-n) & $67.5(2.9)$ & $4.5(2.9)$ & $<0.001$ & $0.4(2.9)$ & 0.423 \\
\hline Midface height (g-sn) & $65.3(5.7)$ & $2.2(5.7)$ & 0.027 & $0.7(5.7)$ & 0.481 \\
\hline Nasal height (n-sn) & $47.6(3.1)$ & $-3.0(3.1)$ & $<0.001$ & $-1.2(3.1)$ & 0.029 \\
\hline Lower face height (sn-me) & $65.0(4.8)$ & $5.2(4.8)$ & $<0.001$ & $-2.0(4.8)$ & 0.013 \\
\hline Upper lip height (sn-sto) & $24.0(2.5)$ & $3.9(2.5)$ & $<0.001$ & $-0.5(2.5)$ & 0.267 \\
\hline Lower lip height (sto-sl) & $20.7(1.1)$ & $2.9(1.1)$ & $<0.001$ & $0.5(1.1)$ & 0.004 \\
\hline Philtrum height & $13.5(1.6)$ & $-0.3(1.6)$ & 0.229 & $-0.5(1.6)$ & 0.052 \\
\hline Lateral commissure height & $22.3(2.3)$ & & & & \\
\hline Upper vermillion height (Is-sto) & $13.4(0.9)$ & $4.7(0.9)$ & $<0.001$ & $0.1(0.9)$ & 0.332 \\
\hline Lower vermillion height (sto-li) & $13.6(1.0)$ & $4.2(1.0)$ & $<0.001$ & $0.4(1.0)$ & 0.031 \\
\hline Chin height (sl-gn) & $34.1(3.2)$ & $7.1(3.2)$ & $<0.001$ & $-1.1(3.2)$ & 0.046 \\
\hline Lower lip to labiomental fold & $10.6(1.1)$ & $-0.2(1.1)$ & 0.401 & $-0.2(1.1)$ & 0.401 \\
\hline
\end{tabular}


Table 6 Comparison of the average facial measurements of the Kenyan male (KM) face and Kenyan female (KF) face with North American whites. NAW data from Farkas et al. [8, 14, 20] and the African-American data from Farkas et al. [8] using one-sample $t$ test (Continued)

\begin{tabular}{|c|c|c|c|c|c|}
\hline & $\begin{array}{l}\text { KM mean } \\
(\mathrm{SD})(n=36)\end{array}$ & $\begin{array}{l}\text { NAW mean (SD) } \\
\text { difference }(n=109)\end{array}$ & $P$ value & $\begin{array}{l}\text { AA mean }(S D) \\
\text { difference }(n=50)\end{array}$ & $P$ value \\
\hline Labiomental fold & $7.9(2.8)$ & & & & \\
\hline Lower lip to menton & $51.6(3.4)$ & $8.2(3.4)$ & $<0.001$ & $-0.5(3.4)$ & 0.399 \\
\hline Nasion to menton & $117.1(5.4)$ & & & & \\
\hline \multicolumn{6}{|l|}{ Horizontal measurements } \\
\hline Intercanthal distance (en-en) & $32.1(1.4)$ & $0.3(1.4)$ & 0.136 & $-2.3(1.4)$ & $<.001$ \\
\hline Eye width (ex-en) & $33.7(1.5)$ & $3.0(1.5)$ & $<0.001$ & $1.5(1.5)$ & $<0.001$ \\
\hline Biocular width (ex-ex) & $94.4(4.9)$ & $6.6(4.9)$ & $<0.001$ & $1.5(4.9)$ & 0.077 \\
\hline Nasal width (al-al) & $40.7(3.7)$ & $9.3(3.7)$ & $<0.001$ & $0.6(3.7)$ & 0.313 \\
\hline Ala curvature $(\mathrm{R}-\mathrm{L})$ & $33.5(2.2)$ & $3.0(2.2)$ & $<0.001$ & $1.3(2.2)$ & 0.019 \\
\hline Mouth width (ch-ch) & $52.0(4.0)$ & $1.8(4.0)$ & 0.008 & $-1.6(4.0)$ & 0.022 \\
\hline Bitemporal width (ft-ft) & $111.2(2.5)$ & $-0.3(2.5)$ & 0.430 & $-0.2(2.5)$ & 0.582 \\
\hline Bizygomatic width (zy-zy) & $130.1(3.5)$ & $0.1(3.5)$ & 0.827 & $-0.4(3.5)$ & 0.523 \\
\hline Bigonial width (go-go) & $96.8(2.9)$ & $2.3(2.9)$ & 0.001 & $0.1(2.9)$ & 0.880 \\
\hline
\end{tabular}

proportionate values (Table 9). Regarding the orbitonasal proportion, none of the participants corresponded with it, with $100 \%$ of the participants exhibiting a greater nasal width compared to the intercanthal distance. The nasofacial proportional canon demonstrated that all the participants had a nasal width greater than the quarter of the facial width (Table 7). All of the proportional indices pertaining to the Kenyan African males and females in our investigation differed significantly from the North American white population, with the greatest mean difference observed in the total upper lip height, intercanthal, and nasal width proportion (Table 8).

\section{Discussion}

Ethnic variability should always be considered during diagnosis and treatment planning of orthognathic or craniofacial reconstructive treatment. Treating subjects from different ethnic groups using normative anthropometric data from another group, or neoclassical canons, for comparison may be misleading and inaccurate $[1,14,15]$.

Clinicians may be faced with the predicament of how to make a distinction between normal and abnormal in a patient's face, due to the presence of a large number of variables [22]. These consist of but are not limited to age, gender, ethnicity, and cultural perceptual variability. In most cases, it is deemed as imperative to treat patients to what constitutes as typical or average for their population, specific for age, gender, and ethnic background. This forms the rationale for establishing normative anthropometric data [1].

Farkas carried out the prevalent comparative studies on intercontinental populations and verified contrasts in the average faces when compared to neoclassical canons $[5,13,18]$. Various other researchers have carried out similar studies on Indian [6], Iranian [23], Turkish [9], Chinese [10], and African American populations [3, 5].

There are numerous methods utilized to obtain anthropometric information, including indirect methods such as photogrammetry and more recently $3 \mathrm{D}$ scanning photogrammetry. However, even with progress, these methodologies may still be considered potentially inferior to direct anthropometric measurements [1, 4]. The main drawbacks to $3 \mathrm{D}$ imaging are the expense and complexity of the equipment, the time-consuming processes required to produce images, and the risk of error if subjects are not stationary through the scanning process $[24,25]$. Errors in software and its utilization may also be relevant factors.

Photogrammetric studies have the advantage of being simpler to conduct as they avoid direct measurements of facial soft tissue and hence may reduce the likelihood of error due to soft tissues displacement [16]. However, photogrammetric measurements are known to be less accurate than direct measured anthropometric analysis [17]. One indirect photogrammetric measurement study carried out comparing Kenyans with Chinese has been described in the literature and demonstrated many differences in average angular measurements of the facial profiles of black Kenyans, Chinese, and white standards [12]. Nevertheless, it is also recognized that direct facial soft tissue anthropometric measurement can be difficult and time-consuming due to the "give" or minor sinking of soft tissue when the measuring instruments are positioned on the facial landmarks [16].

A systematic review utilizing pooled data from studies of various ethnic groups concluded that the height of the forehead, eyes, nose, and mouth exhibited the greatest interethnic variability [26]. In the current investigation, the 
Table 7 Application of neoclassical canons to Kenyan male and female face

\begin{tabular}{|c|c|c|}
\hline Canon II & KM \% & $\mathrm{KF} \%$ \\
\hline $\operatorname{tr}-\mathrm{n}=\mathrm{n}-\mathrm{sn}>1$ & 100 & 100 \\
\hline $\operatorname{tr}-\mathrm{n}=\mathrm{n}-\mathrm{sn}<-1$ & 0 & 0 \\
\hline $\operatorname{tr}-\mathrm{n}=\mathrm{n}-\mathrm{sn}>=-1<=1$ & 0 & 0 \\
\hline \multicolumn{3}{|l|}{ Canon ॥ } \\
\hline $\operatorname{tr}-\mathrm{n}=\mathrm{sn}-\mathrm{me}>1$ & 8 & 30 \\
\hline $\operatorname{tr}-\mathrm{n}=\mathrm{sn}-\mathrm{me}<-1$ & 86 & 59 \\
\hline $\operatorname{tr}-\mathrm{n}=\mathrm{sn}-\mathrm{me}>=-1<=1$ & 6 & 11 \\
\hline \multicolumn{3}{|l|}{ Canon III } \\
\hline $\operatorname{tr}-\mathrm{g}=\mathrm{g}-\mathrm{sn}>1$ & 31 & 3 \\
\hline $\operatorname{tr}-\mathrm{g}=\mathrm{g}-\mathrm{sn}<-1$ & 64 & 95 \\
\hline tr-g $=g-s n>=-1<=1$ & 6 & 3 \\
\hline \multicolumn{3}{|l|}{ Canon V } \\
\hline en-en $=$ al-al > 1 & 0 & 0 \\
\hline en-en $=$ al-al $<-1$ & 100 & 100 \\
\hline en-en $=$ al-al $>=-1<=1$ & 0 & 0 \\
\hline \multicolumn{3}{|l|}{ Canon VI } \\
\hline en-en $=$ ex-en $>1$ & 17 & 8 \\
\hline en-en $=$ ex-en $<-1$ & 50 & 65 \\
\hline en-en $=$ ex-en $>=-1<=1$ & 33 & 27 \\
\hline \multicolumn{3}{|l|}{ Canon VII } \\
\hline ch-ch $=1.5(\mathrm{al}-\mathrm{al})>1$ & 6 & 3 \\
\hline ch-ch $=1.5($ al-al $)<-1$ & 89 & 86 \\
\hline ch-ch $=1.5(\mathrm{al}-\mathrm{al})>=-1<=1$ & 6 & 11 \\
\hline \multicolumn{3}{|l|}{ Canon VIII } \\
\hline $\mathrm{al}-\mathrm{al}=0.25(z y-z y)>1$ & 100 & 100 \\
\hline $\mathrm{al}-\mathrm{al}=0.25(z y-z y)<-1$ & 0 & 0 \\
\hline $\mathrm{al}-\mathrm{al}=0.25(z y-z y)>=-1<=1$ & 0 & 0 \\
\hline
\end{tabular}

anthropometric measurements of both the Kenyan African males and females revealed that the facial characteristics of the population studied varied notably from the North American white subjects. The study further confirmed some similarities to the African American population. When comparing the Kenyan African male to the North American whites, 8 of the 10 measurements were clinically significantly different based on the two-sample $t$ test, and 13 of the 22 measurements were clinically significantly different compared with the one-sample $t$ test. Repeated measures can introduce the likelihood of a type 1 error.

The large number of significantly different proportions with a $p$ value of $<0.001$ demonstrated that this population differed from the NAW. The greatest difference was observed in the reduced nasal height, the increased nasal width, and increased nasal curvature, with the only parameter that was similar between all three populations being the mouth width (ch-ch). A similar trend regarding the labio-oral region being identical was observed in 12 of 13 Caucasian groups, 4 of 5 Asian groups, and all Middle Eastern and African ethnic groups in an international study [16].

When compared to the African American population, the data in this investigation demonstrated no clinically significant differences except for intercanthal distance being reduced in the Kenyan males. However, this finding was significant and distinctive as other studies on African males from Tonga, Angola, Zulu, and African Americans have all been observed intercanthal distance to be identical to NAW $[11,16]$.

Similar results were obtained with the female data with forehead height being greater than the North American whites, though similar to the African Americans. This has also been observed in the Sudanese female face with greater forehead height compared to NAW and AA [16]. The nasal height was shorter for Kenyan African females, though slightly increased compared with African Americans, but this was not significantly different $(p=0.693)$. The nasal width and curvature were greater compared to the North American whites. Between the groups, mouth width was similar and when compared to the African American female, the Kenyan females had greater eye width and intercanthal distance $(p<0.001)$.

The nasolabial and labiomental angular measurements of the Kenyan African male had a clinically significant difference of $10^{\circ}$ when compared with the North American white and the African American subjects. In the Kenyan females, only the nasolabial angle had a clinically significant difference when compared with both populations, with only the labiomental angle

Table 8 Proportional indices comparison of Kenyan African males and females to North American Whites

\begin{tabular}{|c|c|c|c|c|c|}
\hline & KAM & Diff NAW & KAF & Diff NAW & $P$ value \\
\hline Vermillion total upper lip height & $55.9(5.5)$ & $12.8(5.5)$ & $56.3(5.7)$ & $27.5(39.6)$ & $<0.001$ \\
\hline Vermillion cutaneous upper lip height & $99.4(11.1)$ & $11.6(11.1)$ & $99.2(4.8)$ & $11.8(4.8)$ & $<0.001$ \\
\hline Nose- mouth width & $77.3(7.0)$ & $12.0(7.0)$ & $78.7(9.1)$ & $15.4(9.1)$ & $<0.001$ \\
\hline Intercanthal nasal width & $75.2(7.0)$ & $-19.9(7.7)$ & $79.5(7.4)$ & $-21.4(7.4)$ & $<0.001$ \\
\hline Lower face height & $50.1(2.4)$ & $6.4(2.4)$ & $40.7(2.4)$ & $-3.1(2.4)$ & $<0.001$ \\
\hline
\end{tabular}

KAM Kenyan African males, KAF Kenyan African females, NAW North American Whites 
Table 9 Descriptive statistics of measurements of the Kenyan African male and Kenyan African female

\begin{tabular}{|c|c|c|c|c|}
\hline & \multicolumn{2}{|l|}{ Male } & \multicolumn{2}{|c|}{ Female } \\
\hline & Mean & $\begin{array}{l}\text { Standard } \\
\text { deviation } \pm\end{array}$ & Mean & $\begin{array}{l}\text { Standard } \\
\text { deviation } \pm\end{array}$ \\
\hline \multicolumn{5}{|l|}{ Vertical measurements } \\
\hline Forehead height I (tr-g) & 61.4 & 3.2 & 55.4 & 3.3 \\
\hline Forehead height II (tr-n) & 72.2 & 2.3 & 67.5 & 2.9 \\
\hline Midface height (g-sn) & 64.8 & 6.5 & 65.3 & 5.7 \\
\hline Nasal height (n-sn) & 51.0 & 1.9 & 47.6 & 3.1 \\
\hline Lower face height (sn-me) & 76.4 & 3.6 & 69.5 & 4.8 \\
\hline Upper lip height (sn-sto) & 25.5 & 1.3 & 24.0 & 2.5 \\
\hline Lower lip height (sto-sl) & 22.5 & 1.9 & 20.7 & 1.1 \\
\hline Philtrum height (sn-Is) & 15.5 & 1.3 & 13.5 & 1.6 \\
\hline Lateral commissure height & 23.5 & 2.6 & 22.3 & 2.3 \\
\hline Upper vermillion height (Is-sto) & 13.7 & 1.3 & 13.4 & 0.9 \\
\hline Lower vermillion height (sto-li) & 13.8 & 0.9 & 13.6 & 1.0 \\
\hline Chin height (fml-me) & 36.5 & 3.1 & 34.1 & 3.2 \\
\hline Lower lip to labiomental fold & 12.1 & 1.9 & 10.6 & 1.1 \\
\hline Labiomental fold & 8.2 & 1.9 & 7.9 & 2.8 \\
\hline Lower lip to menton & 56.2 & 3.5 & 51.6 & 3.4 \\
\hline Nasion to menton & 101.8 & 3.6 & 117.1 & 5.4 \\
\hline \multicolumn{5}{|l|}{ Horizontal measurements } \\
\hline Intercanthal distance (en-en) & 32.2 & 1.9 & 32.1 & 1.4 \\
\hline Eye width (ex-en) & 34.0 & 3.4 & 33.7 & 1.5 \\
\hline Biocular width (ex-ex) & 98.2 & 3.5 & 94.4 & 4.9 \\
\hline Nasal width (al-al) & 43.2 & 3.8 & 40.7 & 3.7 \\
\hline Ala curvature (ac-ac) & 41.3 & 3.1 & 33.5 & 2.2 \\
\hline Mouth width (ch-ch) & 55.9 & 3.3 & 52.0 & 4.0 \\
\hline Bitemporal width (ft-ft) & 115.3 & 3.4 & 111.2 & 2.5 \\
\hline Bizygomatic width(zy-zy) & 133.8 & 4.6 & 130.1 & 3.5 \\
\hline Bigonial width (go-go) & 106.6 & 5.9 & 96.8 & 2.9 \\
\hline
\end{tabular}

exhibiting a clinical significant difference to the AA female.

When comparing Kenyan faces to Chinese faces, in a photogrammetric study, the only comparable angle was the facial convexity, which was also similar to NAW. The nasal dorsum and lower face height were also comparable in both populations, with all other angular measurements showing large ethnic differences [12].

Despite there only being a difference of $1-2 \mathrm{~mm}$ between some of the measurements, the overall data does propose that the Kenyan population does have a considerable difference in comparison to North American whites and have comparative facial features to the African American populations except for the reduced intercanthal distance observed in the male participants only.

In this investigation, both the Kenyan males and females had reduced intercanthal distance (en-en) compared with the eye fissure length. This was in contrast to the observations in Farkas' international study, where the intercanthal distance was wider than the eye fissure length in the African Americans [20]. The most significant variation was regarding the orbitonasal proportional canon, as none of the participants corresponded with it. In this investigation, the nasofacial proportional canon demonstrated that all the participants had a nasal width greater than a quarter of the facial width. All of the participants exhibited a greater nasal width compared to the intercanthal distance. The Kenyan naso-orbital proportion was similar to the African Americans (94\%) population.

The period coinciding with the European Enlightenment gave rise to the neoclassical proportional canons, which were reworkings based on classical canons [1]. These measurements were predominantly important for artists $[27,28]$. The era of the 17th and 18th centuries 
were immensely influenced by the neoclassical canons, with their influence diminishing by the nineteenth century. Currently, they remain as a classical foundation around which some of modern-day facial analysis is based [1]. However, the results of modern anthropometric studies, and facial attractiveness studies, may update such canons for the modern day $[1,11]$.

In the Kenyan sample, the neoclassical canons of facial proportion were not applicable. This has been observed in similar investigations on African American males and African American females [17]. The vertical facial trisection canon for upper, middle, and lower facial heights being equal thirds was not observed. The middle third of the face was identified as being the smallest of the three proportions. The most frequently valid canon tested was the orbital canon, being valid in 33\% of the males and $27 \%$ of the females, which was comparable to previous studies $[8,13]$.

The anthropometric data from this investigation, in terms of linear measurements (Table 9), angular measurements (Tables 4 and 5), and proportional values (Table 8) described, provides a potentially valuable data set, and could serve as a database for facial analysis in the Kenyan African population.

\section{Conclusion}

This is the first anthropometric study on Kenyan males and females, testing the validity of the neoclassical canons and providing a database for the average horizontal and vertical measurements and proportions of the population.

Young adult Kenyan males and females were chosen for this investigation because they form the main ethnic group in Kenya. The participants were ethnic Kenyans studying at the University of Nairobi and within the limitations of this study the normative data provided may be used to represent the Kenyan normative values.

In general, it was observed that both the Kenyan males and females had a trend for an increased forehead height $(\sim 5 \mathrm{~mm})$ compared to the reduced middle third of the face and reduced nasal height $(\sim 4 \mathrm{~mm})$, and taller lower face $(\sim 4-5 \mathrm{~mm})$. The most distinguishing feature was the increased nasal width $(\sim 8 \mathrm{~mm})$ and wider eye fissure length compared to the intercanthal distance. Upper lip height was also significantly greater in the Kenyan population $(\sim 3-4 \mathrm{~mm})$. Despite the previously reported differences of other African ethnic groups, such as Sudanese females, the Kenyan population sampled in this investigation had comparable facial features to the African American populations, except for the reduced intercanthal distance observed in the male participants only.

None of the neoclassical canons were valid for this group of young Kenyan adults. This study does verify that anthropometric measurements of Caucasian populations are invalid when applied to the Kenyan population, and variations do exist in comparison with African American normative data. It is recommended that accurate and applicable data is used in diagnosis and treatment planning for each ethnic group.

\section{Acknowledgements \\ This study would not have been possible without the involvement of all the participants and staff at the University of Nairobi. \\ Funding \\ None. \\ Availability of data and materials \\ Please contact author for data requests. \\ Authors' contributions \\ FBN conceived the study. FBN, SSV, and DW designed and coordinated the study. SSV collected the data. DW undertook the statistical analysis. All authors helped to complete the manuscript and read and approved the final manuscript.}

Ethics approval and consent to participate

Ethical approval was obtained; REC (University of Nairobi) reference: $\mathrm{KNH}-\mathrm{ERC} / \mathrm{A} / 289$.

\section{Consent for publication}

The subjects in Figs. 1, 2, and 3 provided written consent for their images to be published.

\section{Competing interests}

The authors declare that they have no competing interests.

\section{Publisher's Note}

Springer Nature remains neutral with regard to jurisdictional claims in published maps and institutional affiliations.

\section{Author details}

${ }^{1}$ Department of Orthodontics, St George's Hospital and King's College London, London, UK. 'Faculty of Science, Engineering and Computing, Kingston University, London, UK. ${ }^{3}$ Kingston and St George's Hospitals and St George's Medical School, London, UK.

Received: 14 January 2019 Accepted: 31 January 2019

Published online: 22 February 2019

\section{References}

1. Naini FB (2011) Facial aesthetics: concepts and clinical diagnosis. WileyBlackwell, Oxford

2. Hrdlička A (1939) Practical anthropometry. Wistar Institute, Philadelphia

3. Farkas LG (1994) Anthropometry of the head and face. Raven Press, New York

4. Arslan SG, Genc C, Odabas B, Kama JD (2008) Comparison of facial proportions and anthropometric norms among Turkish young adults with different face types. Aesth Plast Surg 32:234-242

5. Naini FB, Gill DS (2017). Principles of orthognathic treatment planning. In: Naini FB, Gill DS (eds). Orthognathic surgery: Principles, planning and practice. Wiley-Blackwell, Oxford

6. Jagadish Chandra H, Ravi MS, Sharma SM, Rajendra Prasad B (2012) Standards of facial esthetics: an anthropometric study. J Maxillofac Oral Surg 11:384-389

7. Khan N, Leela V, Gopalakrishna A (2012) A study of craniofacial anthropometrics in Hyderabad (Deccan) and a review of literature. J Med Allied Sci 2:54-57

8. Farkas LG, Katic MJ, Forrest CR (2007) Comparison of craniofacial measurements of young adult African-American and North American white males and females. Ann Plast Surg 59:692-698 
9. Borman H, Ozgur F, Gursu G (1999) Evaluation of soft-tissue morphology of the face in 1,050 young adults. Ann Plast Surg 42:280-288

10. Le $T$, Farkas LG, Ngim RC, Levin LS, Forrest CR (2002) Proportionality in Asian and North American Caucasian faces using neoclassical facial canons as criteria. Aesth Plast Surg 26:64-69

11. Salah M, Higzi MA, Ali RW, Naini FB (2014) The Sudanese female face: normative craniofacial measurements and comparison with AfricanAmerican and North American White females. J Craniomaxillofac Surg 42: 1704-1709

12. Wamalwa P, Amisi SK, Wang Y, Chen S (2011) Angular photogrammetric comparison of the soft-tissue facial profile of Kenyans and Chinese. J Craniofac Surg 22:1064-1072

13. Farkas LG, Cheung G (1981) Facial asymmetry in healthy north American Caucasians. An anthropometrical study. Angle Orthod 51:70-77

14. Farkas $L G$, Forrest CR, Litsas $L$ (2000) Revision of neoclassical facial canons in young adult Afro-Americans. Aesth Plast Surg 24:179-184

15. Farkas LG (1996) Accuracy of anthropometric measurements: past, present, and future. Cleft Palate Craniofac J 33:10-18

16. Farkas $L G$, Katic MJ, Forrest CR (2005) Anthropometric proportion indices in the craniofacial regions of 73 patients with forms of isolated coronal synostosis. Ann Plast Surg 55:495-499

17. Porter JP, Olson KL (2001) Anthropometric facial analysis of the African American woman. Arch Facial Plast Surg 3:191-197

18. Farkas LG, Bryson W, Klotz J (1980) Is photogrammetry of the face reliable? Plast Reconstr Surg 66:346-355

19. Jeffries JM 3rd, DiBernardo B, Rauscher GE (1995) Computer analysis of the African-American face. Ann Plast Surg 34:318-321

20. Naini FB, Gill DS (2017). Patient evaluation and clinical diagnosis. In: Naini FB, Gill DS (eds). Orthognathic surgery: Principles, planning and practice. Wiley-Blackwell, Oxford

21. Othman SA, Majawit LP, Wan Hassan WN, Wey MC, Mohd Razi R (2016) Anthropometric study of three-dimensional facial morphology in Malay adults. PLoS One 11:e0164180

22. Tessier P (1987) An interview with Paul Tessier conducted by Lars M Vistnes, M.D. Ann Plast Surg 18:352-354

23. Jahanshahi M, Golalipour MJ, Heidari K (2008) The effect of ethnicity on facial anthropometry in Northern Iran. Singap Med J 49:940-943

24. Bush K, Antonyshyn O (1996) Three-dimensional facial anthropometry using a laser surface scanner: validation of the technique. Plast Reconstr Surg 98:226-235

25. Moss JP, Ismail SF, Hennessy RJ (2003) Three-dimensional assessment of treatment outcomes on the face. Orthod Craniofac Res 6:126-131

26. Fang F, Clapham PJ, Chung KC (2011) A systematic review of interethnic variability in facial dimensions. Plast Reconstr Surg 127:874-881

27. Broadbent TR, Mathews VL (1957) Artistic relationships in surface anatomy of the face: application to reconstructive surgery. Plast Reconstr Surg (1946) 20:1-17

28. Seghers MJ, Longacre JJ, Destefano GA (1964) The Golden proportion and beauty. Plast Reconstr Surg 34:382-386

\section{Submit your manuscript to a SpringerOpen ${ }^{\circ}$ journal and benefit from:}

- Convenient online submission

- Rigorous peer review

- Open access: articles freely available online

- High visibility within the field

- Retaining the copyright to your article

Submit your next manuscript at $\boldsymbol{\nabla}$ springeropen.com 